\title{
ANALISIS ALGORITMA GENETIKA UNTUK PENCARIAN RUTE OPTIMUM PADA PENGIRIMAN HASIL PRODUKSI \\ TAHU
}

\author{
R. Fitria. Rachmawati, Anwar Nasrudin \\ STIKOM Binaniaga Bogor, Program Studi Teknik Informatika \\ Email: rachmawati.ft@gmail.com
}

\section{ABSTRACT}

The delivery of the tofu production is done based on the usual route by the driver without a clear calculation of which route to select, so that the driver actually goes through the optimum path. It affects the cost of shipping tofu and the timeliness of goods to the customer. Genetic Algorithm is one of the very good problem solving methods because it has very complex problem solving options. Using distance data between genetic algorithm delivery points can provide the right solution which path is the most optimum driver can pass when shipping know, so the cost of distribution can be more minimum and the time required to do delivery can be faster. Result of feasibility test on Application This delivery route get the percentage value of $81,2 \%$ so it can be concluded that the application of delivery route is feasible to be used.

Keywords: Genetic Algorithm,Optimum Route,Application of the delivery route.

\begin{abstract}
ABSTRAK
Pengiriman hasil produksi tahu dilakukan berdasarkan jalur yang biasa dilalui oleh driver, tanpa perhitungan yang jelas tentang rute mana yang harus dipilih sehingga driver benar-benar melalui jalur yang optimum. Hal tersebut berpengaruh terhadap biaya pengiriman tahu dan ketepatan waktu barang sampai ke pelanggan. Algoritma Genetika adalah salah satu metode pemecahan masalah yang sangat bagus karena memiliki pilihan pemecahan masalah yang sangat kompleks. Dengan menggunakan data jarak antar titik pengiriman algoritma genetika bisa memberikan solusi yang tepat jalur mana yang paling optimum yang bisa dilalui driver ketika melakukan pengiriman tahu, sehingga biaya distribusi bisa lebih minimum dan waktu yang dibutuhkan untuk melakukan pengriman bisa lebih cepat. Hasil pengujian kelayakan terhadap Aplikasi Rute pengiriman ini mendapatkan nilai presentase sebesar 81,2 \% sehingga dapat disimpulkan bahwa aplikasi rute pengiriman layak digunakan.
\end{abstract}

Kata Kunci: Algoritma Genetika,Rute Optimum,Aplikasi Rute Pengiriman

\section{PENDAHULUAN}

A. Latar Belakang

Pendistribusian barang hasil produksi merupakan salah satu faktor penting dalam suatu usaha dagang. Setiap perusahaan selalu memperhitungkan biaya yang harus dikeluarkan untuk mendistribusikan barang dagangan mereka. Selain harga bahan baku,biaya produksi,dan gaji karyawan,biaya distribusi yang dikeluarkan juga menjadi faktor yang cukup penting dan menjadi bahan pertimbangan dalam menentukan harga jual produk. Semakin besar biaya distribusi maka harga jual produk juga harus besar sedangkan jika produk yang sama yang dimiliki pesaing harganya lebih murah maka produknya akan kalah saing dipasaran. Oleh karena itu harus diupayakan untuk mengeluarkan biaya distribusi yang sangat minimum. 
Beberapa hal yang menjadi pertimbangan para pengrajin tahu dalam menentukan harga jual produk mereka adalah harga bahan baku, biaya produksi ,dan biaya distribusi. Faktor yang terakhir yang terakhir yang mempengaruhi harga jual dan keuntungan pengrajin tahu adalah biaya distribusi. Semakin besar biaya distribusi semakin besar pula harga jual yang harus ditentukan untuk mengimbangi keuntungan yang ingin diperoleh oleh pemilik perusahaan. Sedangkan persaingan di bagian pemasaran sangat ketat.Apabila pengrajin menaikan harga sedikit saja di pasaran sedangkan pengrajin yang lainnya tidak menaikkannya maka perusahaan yang menaikkan harga tahu tersebut akan kalah dalam persaingan di pasaran. Solusi yang kedua yang mungkin bisa diambil oleh pengrajin jika tidak ingin menaikkan harga di pasaran adalah mengurangi target keuntungan yang ingin diperoleh para pemilik perusahaan.Kebanyakan para pengrajin tahu memakai solusi yang kedua ini karena mereka berfikir keuntungan sedikitpun asal bisa tetap produksi padahal dalam bidang usaha tentunya kita ingin mendapatkan keuntungan yang besar. Di perusahaan UD Tahu Bandung Cap “ Jempol” Raos untuk distribusi barang sampai bulan februari 2017 menggunakan 3 kendaran dengan biaya perhari rata-rata sekitar Rp 510.000. Tetapi karena alasan keterlambatan pengiriman barang hasil produksi yaitu tahu ke pelanggan,pada awal bulan maret 2017 pemilik perusahaan melakukan penambahan mobil yang digunakan untuk pendistribusian barang sebanyak 1 unit mobil. Jadi total mobil yang digunakan untuk pendistribusian barang tersebut sampai 4 unit mobil. Ketika sebelumnya menggunakan 3 mobil saja biaya distribusi yang harus dikeluarkan oleh perusahaan sebesar Rp 14.307.000,- selama bulan Februari 2017. Untuk sekarang ditambah lagi satu unit mobil sudah dapat dipastikan biaya distribusinya pun pasti meningkat.

UD Tahu Bandung Cap “ Jempol” Raos menggunakan 3 mobil untuk pendistribusian barang hasil produksi tahu yaitu mobil 1 untuk pendistribusian barang di daerah Bogor.Mobil ke 2 dugunakan untuk pendistribusian barang ke daerah Jakarta dan mobil ke 3 digunakan untuk pendistribusian barang ke daerah Sukabumi. Dari datadata yang ada Mobil ke 3 merupakan yang paling besar biaya distribusinya.

Berdasarkan keterangan para driver khususnya jalur yang dipakai mobil ke 3 yaitu jalur pengiriman daerah sukabumi faktor yang menyebabkan keterlambatan adalah banyaknya terjadi kemacetan dan tempat pengiriman barang yang cukup berjauhan. Padahal banyak jalan yang bisa dilalui seandainya ada yang bisa mengatur lintasa mana yg bisa dilewati tanpa harus mengalami keterlambatan pengiriman dan tentu saja bisa meminimalisir biaya distribusi. 
Pendistribusian barang dari tempat produksi sampai ke konsumen memiliki beberapa kendala yang menyebabkan membesarnya biaya distribusi barang tersebut. Untuk mobil 1 tidak mengalami kendala yang cukup berarti karena pengiriman dilakukan di malam hari sehingga tidak terganggu dengan kemacetan di jalan. Mobil 1 mulai berangkat melakukan pengiriman ke 5 tempat yang cukup berjauhan. Untuk menghemat biaya distribusinya bisa disiasati dengan melakukan pengiriman ke 2 tempat dalam sekali berangkat. Misalnya jalur ciampea dan lewi liang bisa dilakukan dalam satu kali keberangkatan kalau memang barangnya bisa muat dalam satu mobil.Untuk jalur lainnya pengiriman ke pasar merdeka dan pasar sawo jajar bisa sekali pengirman. Begitu juga dengan pasar empang dan pasar bogor. Untuk mobil ke 2 melakukan pengiriman barang ke pasar cisalak dan pasar citeureup, ada kendala dalam jalur pengiriman ini yaitu jarak kedua tempat yang berjauhan dan sering mengalami kemacetan di beberapa titik sehingga harus di tentukan mobil tersebut harus melewati jalan yang mana agar bisa meminimalisir biaya distribusi. Walaupun sudah melalui jalan tol mobil ini tetap bisa terjebak macet di beberapa titik yaitu di sekitar pasar citeureup dan di jalan baru. Dengan pemilihan jalur yang tepat mobil tersebut bisa menggunakan biaya distribusi yang lebih sedikit.

Mobil 3 dan mobil 4 merupakan mobil yang memiliki paling banyak permasalahan dalam pendistribusian barangnya sehingga biaya distribusinya juga lebih besar. Selain jaraknya yang sangat jauh mobil ini sering menemui tititk-titik kemacetan yang berbeda-beda setiap hari. Banyak sekali jalur yang dapat dilewati kedua mobil ini namun supir tidak bisa menentukan jalan mana yang harus dilewati. Dengan menentukan rute yang tepat yang harus dilewati setiap harinya biaya distribusi untuk kedua mobil ini akan berkurang sangat besar.

Algoritma genetika adalah model algoritmik yang dikembangkan untuk mensimulasikan sistem genetik. Algoritma genetika telah banyak diaplikasikan untuk penyelesaian masalah dan pemodelan dalam bidang teknologi,bisnis, dan entertainment seperti optimasi,pemrograman otomatis, mechine learning, model ekonomi,model sistem imunisasi,model ekologis hingga interaksi anatar evolusi dan belajar. DE Goldberg mendefinisikan algoritma genetika sebagai algoritma pencarian yang didasarkan pada mekanisme seleksi alamiah dan genetika alamiah ( Suyanto, 2005, hal.5 )

B. Rumusan Masalah

Peningkatan biaya distribusi barang biasanya dipengaruhi oleh jarak perusahaan dengan tempat pengriman barang dan juga kendala diperjalanan yaitu kemacetan. Oleh karena itu dapat diidentifikasi masalah yang ada yaitu : 
1. Belum adanya metode untuk memilih rute pengiriman yang optimum sehingga bisa meminimalisir biaya distribusi.

2. Belum adanya cara untuk mengevaluasi pemilihan rute pengiriman barang yang paling optimum.

C. Maksud dan Tujuan Penelitian

1. Maksud Penelitian

Melakukan penerapan algoritma genetika untuk optimalisasi pengiriman hasil produksi tahu.

2. Tujuan Penelitian

a. Mendapatkan metode untuk memilih rute optimum yang bisa meminimalisir biaya distribusi barang hasil produksi tahu.

b. Mendapatkan cara yang dapat digunakan untuk mengevaluasi penentuan rute pengiriman hasil produksi tahu yang paling optimum

D. Tinjuan Pustaka

Algoritma genetika merupakan suatu metode heuristik yang dikembangkan berdasarkan prinsip genetika dan proses seleksi alamiah teori Evolusi Darwin.Metode Optimasi dikembangkan oleh John Holland sekitar tahun 1960-an dan dipopulerkan oleh salah seorang mahasiswanya David Goldberg pada tahun 1980-an( Haupt dan Haupt,2004).Proses pencarian penyelesaian atau proses terpilihnya sebuah penyelesaian dalam algoritma ini berlangsung sama seperti terpilihnya suatu individu untuk bertahan hidup dalam proses evolusi.

Terdapat beberapa kelebihan Algoritma Genetika jika dibandingkan dengan algoritma pencarian lainnya. Menurut Gen dan Cheng ( 1997 ),kelebihan-kelebihan tersebut adalah :

1. Algoritma ini hanya melakukan sedikit perhitungan matematis yang berhubungan dengan masalah yang ingin diselesaikan. Karena sifat perubahan evolusi alamiahnya,maka algoritma ini akan mencari penyelesaian tanpa memperhatikan proses-proses yang berhubungan dengan masalah yang diselesaikan secara langsung.Algoritma ini juga dapat mengendalikan fungsi objektif dan kendala yang didefinisikan, baik pada ruang pencairan diskrit, maupun ruang pencarian analog.

2. Operator-operator evolusi membuat algoritma ini sangat efektif pada pencarian global.

3. Algoritma ini memiliki fleksibilitas yang tinggi untuk dihibridkan dengan metode pencarian lainnya supaya lebih efektif.

Secara singkat, pemetaan proses alamiah ke dalam proses komputasi algoritma genetika dapat dirangkum dalam tabel 1 : 
Tabel 1. Pemetaan Proses Alamiah Kedalam Proses Komputasi

\begin{tabular}{|l|l|}
\hline \multicolumn{1}{|c|}{ Proses alamiah } & \\
\hline Individu & Penyelesaian Masalah \\
\hline Populasi & Himpunan Penyelesaian \\
\hline Fitness/kebugaran & Kualitas penyelesaian \\
\hline Kromosom & Kode/refresentasi penyelesaian \\
\hline Gen & Bagian dari representasi penyelesaian \\
\hline Pertumbuhan & Pendekodean representasi penyelesaian \\
\hline Penyilangan & Operator genetika \\
\hline Mutasi & Operator genetika \\
\hline Seleksi Alam & Menyeleksi penyelesaian masalah (sementara) berdasarkan kualitasnya. \\
\hline
\end{tabular}

\section{METODE}

\section{A. Desain Penelitian}

Desain penelitian merupakan langkah-langkah dari proses penelitian yang dilakukan. Prosedur penelitian dalam penelitian yang akan dilakukan dapat digambarkan pada gambar 1 :

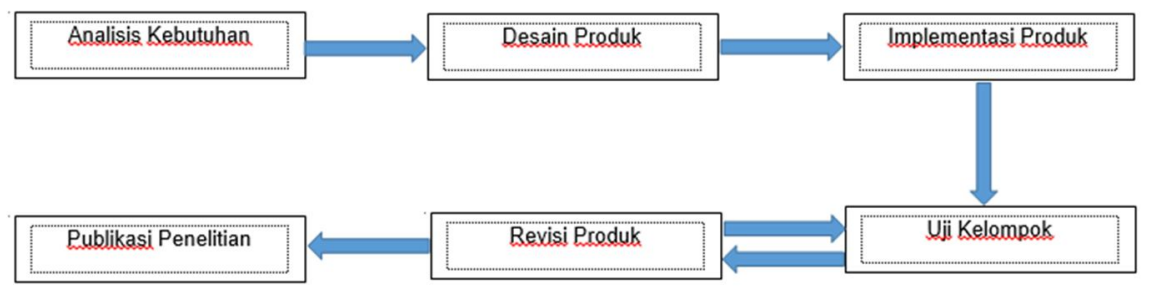

Gambar 1. Prosedur Penelitian

Gambar 1 adalah gambar prosedur penelitian yang dapat dijelaskan sebagai berikut :

1. Analisa Kebutuhan, yaitu pengumpulan data-data yang diperlukan untuk digunakan sebagai dasar dari pengembangan sistem penerima bantuan.

2. Desain, yaitu pendefinisian dari kebutuhan-kebutuhan fungsional dan persiapan untuk rancang bangun implementasi; menggambarkan bagaimana sistem penerima bantuan dibentuk

3. Implementasi, yaitu penerapan sistem yang sudah sesuai dengan kebutuhan untuk digunakan.

4. Uji Kelompok, yaitu menguji coba produk yang telah diperbaiki pada tahap awal uji coba kepada pengguna

5. Revisi, yaitu memperbaiki produk yang telah di uji coba pada tahap uji coba kelompok

6. Publikasi Penelitian,yaitu produk yang telah melalui tahap uji coba bahwa produk layak digunakan.

B. Populasi dan Sampel

Subjek pengguna yang terlibat pada penelitian ini yaitu pemilik perusahaan, bagian manajemen dan pihak yang terlibat dalam pendistribusian tahu untuk bisa sampai ke konsumen. 
C. Jenis Data

Jenis data dimaksudkan untuk mengumpulkan data yang dapat digunakan sebagai dasar untuk menetapkan tingkat keefektifan, efisiensi dan daya tarik dari produk yang dihasilkan.

D. Instrumen Pengumpulan Data

Instrumen pengumpulan data merupakan Instrumen yang disusun meliputi komponenkomponen yang dilihat dari pengguna,yaitu data-data yang digunakan untuk memperoleh data untuk menjadikan sebuah sitem yang baik dan mudah digunakan sesuai dengan keinginan pengguna.

E. Teknik Analisa Data

Data-data yang diperoleh melalui instrumen penilaian pada saat uji coba dianalisis dengan menggunakan statistik deskriptif kualitatif. Analisis ini dimaksudkan untuk menggambarkan karakteristik data pada masing-masing variabel. Dengan cara ini diharapkan akan mempermudah memahami data untuk proses analisis selanjutnya. Hasil analisis data digunakan sebagai dasar untuk merevisi produk persediaan bahan baku yang dikembangkan. Teknik analisis data yang dilakukan adalah menggunakan teknik analisis deskriptif kualitatif yaitu memaparkan tentang jalur-jalur yang dilalui untuk pengiriman hasil prosukdi tahu berbasis komputer, menguji tingkat validasi dan kelayakan produk untuk diimplementasikan yang terkumpul diproses dengan cara dijumlahkan, dibandingkan dengan jumlah yang diharapkan dan diperoleh persentase (Arikunto, 1996: 244), atau dapat ditulis dengan rumus sebagai berikut.

$$
\text { Persentase Kelayakan }=\frac{\text { Skor yang diobservasi }}{\text { Skor yang di harapkan }} \times 100 \%
$$

Hasil Presentase digunakan untuk memberikan jawaban atas kelayakan dari aspek-aspek yang diteliti. Menurut Arikunto (2009: 44) pembagian kategori kelayakan ada lima. Skala ini memperhatikan rentang dari bilangan presentase. Nilai maksimal yang diharapkan adalah $100 \%$ dan minimum 0\%. Pembagian rentang kategori kelayakan menurut arikunto (2009: 44) dapat dilihat pada tabel 2 .

Tabel 2. Kategori kelayakan

\begin{tabular}{|c|c|}
\hline Presentase Pencapaian & Interpretasi \\
\hline$<21 \%$ & Sangat Tidak Layak \\
\hline $21 \%-40 \%$ & Tidak Layak \\
\hline $41 \%-60 \%$ & Cukup layak \\
\hline $61 \%-80 \%$ & Layak \\
\hline $81 \%-100 \%$ & Sangat Layak \\
\hline
\end{tabular}

$$
\text { Sumber : Arikunto (2009:44) }
$$

Pada tabel 3.4 disebutkan presentase pencapaian, skala nilai, dan interprestasi. Untuk mengetahui kelayakan digunakan tabel 2 sebagai acuan penilaian data 


\section{HASIL DAN PEMBAHASAN}

\section{Hasil Penelitian}

\section{A. Analisa Kebutuhan}

UD Tahu Bandung Cap “ Jempol “ Raos adalah suatu perusahaan kecil menengah yang bergerak di bidang produksi makanan yaitu tahu.Dalam proses pendistribusian barangnya tidak ada SOP yang jelas sehingga terjadi beberapa permasalahan yang menyebabkan kurangnya efisiensi waktu dan biaya.

Permasalahan yang timbul dalam proses pendistribusiannya adalah tidak adanya penugasan yang jelas dalam pengiriman tahu sehingga sering terjadinya barang kiriman yang ketinggalan dan rute pengiriman yang tidak ditentukan oleh perusahaan sehingga menimbulkan biaya distribusi yang melonjak.

Proses Bisnis Sebelum dilakukan pengembangan adalah Proses pengiriman tahu dilakukan oleh driver tanpa memperhitungkan jarak yang ditempuh selain itu barang yang dikirim juga hanya berdasarkan perkiraan box tahu yang dimiliki oleh masingmasing pedagang/pelanggan.

Setelah dianalisis proses bisnis yang ada saat ini dalam proses pendistribusian tahu agar sampai kepelanggan belum ada kejelasan dalam pengiriman tersebut yaitu :

1. Tidak ada penugasan yang pasti tentang jumlah barang yang harus dikirim untuk setiap pelanggan.

2. Tidak ada penentuan jalur yang harus ditempuh sehingga menimbulkan pembengkakan biaya distribusi karena driver tidak memilih jalur yang optimum.

Setelah dilakukan analisis tentang permasalahan yang timbul di Perusahaan UD Tahu Bandung Cap “Jempol” Raos tentang pengiriman tahu.Ada beberapa rekomendasi yang diajukan penulis yaitu :

1. Aplikasi

Penulis merekomendasikan perancangan sebuah aplikasi yang bisa memecahkan permasalahan dalam pengiriman tahu yaitu aplikasi pendistribusian tahu.Adapun hasil output dari aplikasi tersebut adalah surat penugasan tentang rute pengiriman yang harus dilalui driver dan berisi tentang data-data pengiriman tahu yang harus dilakukan oleh driver.

2. Metode

Metode yang digunakan dalam merancang aplikasi Pendistribusian Tahu tersebut adalah algoritma gentika

3. Perhitungan

Penggunaan piranti lunak dalam penelitian ini mengikuti tahapan-tahapan yang ada pada algoritma genetika secara umum. Yaitu seperti terlihat pada gambar 2. 


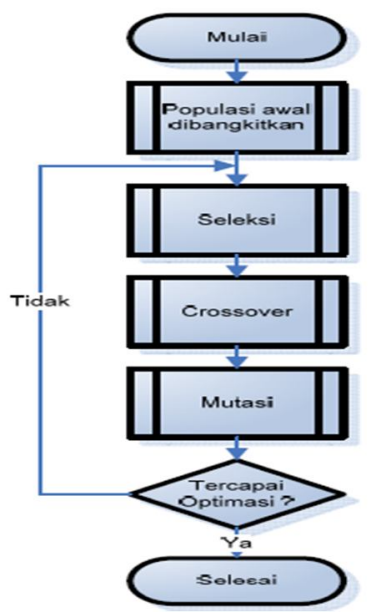

Gambar 2. Flowchart Algoritma Genetika dalam Perangkat Lunak

Proses algoritma genetika dimulai dengan membangkitkan populasi awal yang akan dihitung . Selanjutnya dilakukan proses seleksi terhadap populasi yang telah dibangkitkan. Setelah proses seleksi dilakukan proses crosscover untuk mencari populasi yang lebih baik. Setelah itu dilakukan proses mutasi sampai tercapai nilai yang paling optimum jika belum maksimum dilakukan proses looping dari tahap seleksi.

\section{Teknik Encoding}

Proses encoding adalah salah satu proses yang sulit dalam algoritma genetika. Hal ini disebabkan karena proses encoding untuk setiap permasalahan berbeda-beda karena tidak semua teknik encoding cocok untuk setiap permasalahan. Proses encoding menghasilkan string yang kemudian disebut kromosom. String terdiri dari sekumpulan bit. Bit ini dikenal sebagai gen. Jadi satu kromosom terdiri dari sejumlah gen. Ada bermacam-macam teknik encoding yang dapat dilakukan dalam algoritma genetika. Beberapa teknik-teknik encoding itu antara lain adalah binary encoding, permutation encoding, value encoding serta tree encoding. Teknik encoding yang digunakan pada penelitian ini adalah permutation encoding dan value encoding. Pada permutation encoding, kromosom-kromosom adalah kumpulan angka yang mewakili posisi dalam sebuah rangkaian.

Pada pencarian jalur distribusi ini, kromosom mewakili urutan kota sebagai jalur distribusi. Jadi apabila satu kromosom berbentuk sebagai berikut $\mathrm{P} 1=(\mathrm{X} 1, \mathrm{X} 2, \mathrm{X} 3, . ., \mathrm{Xn})$ berarti jalur distribusi bergerak dari kota bernomor X1 ke X2 dst hingga ke kota ke Xn. Sedangkan Pada value encoding, setiap kota tujuan distribusi diwakili oleh sebuah angka, dan angka tersebut merupakan sebuah gen yang ada pada sebuah kromosom. Setiap kromosom yang ada pada satu generasi merepresentasikan kombinasi jalur distribusi barang yang digunakan untuk mendapatkan hasil yang optimal. 
Proses seleksi adalah proses yang memegang peranan penting dalam algoritma genetika. Proses seleksi ini digunakan agar hanya kromosom-kromosom yang berkualitas yang dapat melanjutkan peranannya dalam proses algoritma genetika berikutnya. Ada bermacam-macam teknik untuk melakukan proses seleksi pada suatu permasalahan. Teknik seleksi yang akan digunakan tergantung pada permasalahan yang akan diselesaikan. Ada beberapa metode seleksi dari induk, diantaranya adalah Rank-based Fitness Assignment, Roulette Wheel Selection, Stochastic Universal Sampling, Local Selection, Truncation Selection, Tournament Selection [2].Proses penyeleksian yang digunakan disini adalah Roulette Wheel Selection. Pada proses penyeleksian digunakan suatu parameter yang disebut kesesuaian atau fitness. Fitness digunakan untuk menentukan seberapa baik kromosom akan bertahan hidup. Penentuan berapa besar nilai fitness suatu kromosom berdasarkan fungsi fitness yang didefinisikan tersendiri. Untuk makalah ini maka fungsi fitness didefinisikan sebagai:

Fitness $=$ Total Jarak

Untuk menghitung nilai fitness dalam kasus ini, yang dibutuhkan untuk inisialisasi data awal adalah jarak antara tempat pelanggan tahu yang biasa dikirim oleh UD. Tahu Bandung Cap “ Jempol “ Raos.

Tabel 3. Jarak Pelanggan UD Tahu Bandung Cap “Jempol” Raos Jalur Bogor

\begin{tabular}{|c|c|c|c|c|c|c|}
\hline & Pabrik & Ciampea & Leuwiliang & Merdeka & Ps Anyar & Ps Bogor \\
\hline Pabrik & 0 & 10 & 16 & 10 & 11 & 13 \\
\hline Ciampea & 10 & 0 & 11 & 15 & 16 & 20 \\
\hline Leuwiliang & 16 & 11 & 0 & 22 & 23 & 29 \\
\hline Merdeka & 10 & 15 & 22 & 0 & 2 & 6 \\
\hline Ps Anyar & 10 & 23 & 16 & 2 & 0 & 4 \\
\hline Ps Bogor & 13 & 29 & 20 & 6 & 4 & 0 \\
\hline
\end{tabular}

Untuk memudahkan penamaan misalkan kita buat kode untuk masing-masing tempat tujuan pengiriman sebagai berikut :

Tabel 4. Kode Tempat Pelanggan Tahu

\begin{tabular}{|c|c|c|}
\hline No. & Nama Tempat Pelanggan & Kode \\
\hline 1 & Pabrik & A \\
\hline 2 & Ciampea & B \\
\hline 3 & Leuwiliang & C \\
\hline 4 & Merdeka & D \\
\hline 5 & Ps Anyar & E \\
\hline 6 & Ps Bogor & F \\
\hline
\end{tabular}




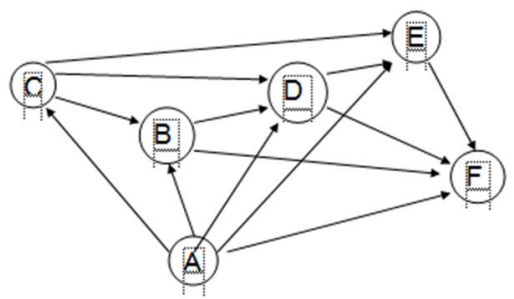

Gambar 3. Diagram graf pelanggan UD Tahu Bandung Cap " Jempol " Raos

\section{B. Implementasi}

Tampilan Cek Rute Pengiriman berfungsi untuk melakukan proses pencarian solusi pemilihan rute optimum secara algoritma genetika. User harus memilih kelompok pengiriman terlebih dahulu setelah itu menetukan titik awal pengiriman.lalu menginputkan bagian-bagian yang dibutuhkan dalam memproses algoritma genetika yaitu jumlah kromosonm,generasi,dll.

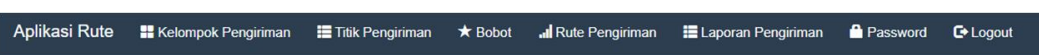

Cek Rute Pengiriman

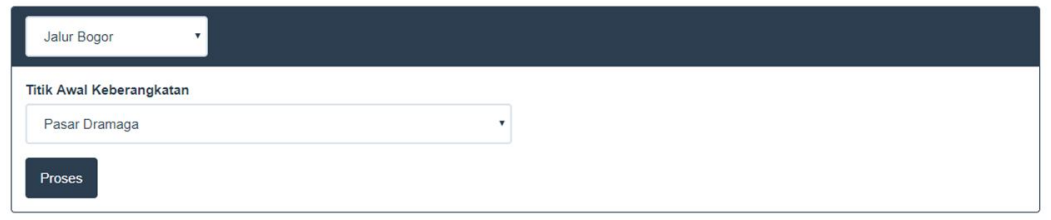

Gambar 4. Tampilan perhitungan Algoritma genetika

Setelah dilakukan proses algoritma genetika. Selanjutnya akan ditampilkan rute hasil proses algoritma genetika yang paling optimum yang harus dilalui driver ketika melakukan pengiriman tahu.

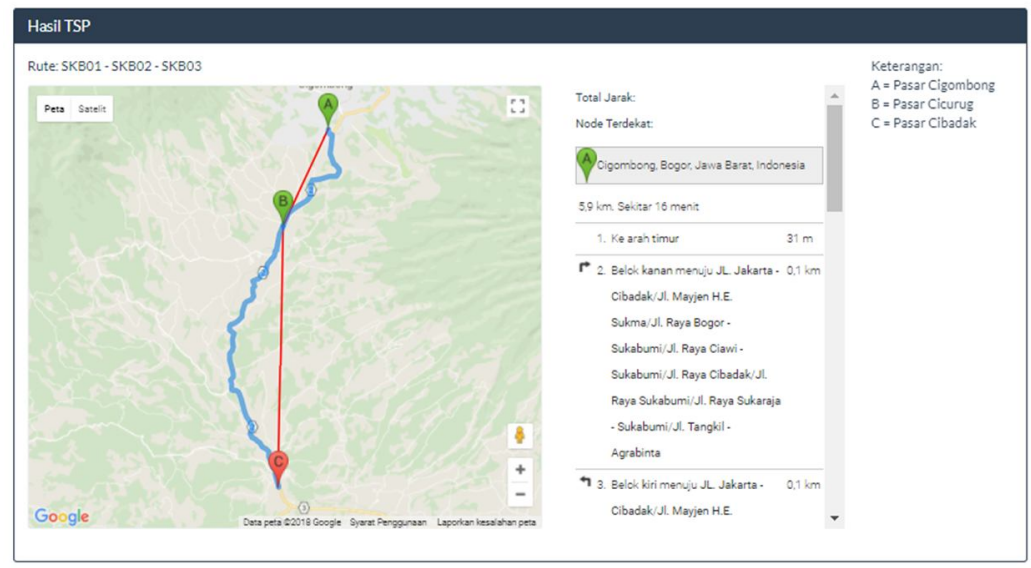

Gambar 5. Tampilan perhitungan Algoritma genetika

Hasil penelitian disajikan dengan lengkap dan sesuai ruang lingkup penelitian. Hasil penelitian dapat dilengkapi dengan tabel, grafik (gambar), dan/atau bagan. Tabel dan gambar diberi nomor dan judul. Hasil analisis data dimaknai dengan benar. 


\section{Pembahasan}

Aplikasi ini dilihat dan coba digunakan oleh pelanggan, dengan menilai apakah sistem ini sudah sesuai dengan kebutuhan yang ada UD Tahu Bandung Cap “ Jempol " Raos tersebut, adapun penilaian yang dilakukan dengan cara menguji aplikasi yang sudah dibuat dan penilaian pun dilakukan dengan menggunakan metode penyebaran kuesioener kepada pengguna yaitu bagian diver dan pemilik perusahaan, berikut penilaian kuesioner tersebut:

$$
\begin{aligned}
& \qquad \text { Persentase kelayakan }(\%)=\frac{\text { Skor yang diobservasi }}{\text { Skor yang diharapkan }} \times 100 \% \\
& \text { Persentase kelayakan }(\%)=\frac{40+40+41+40+42}{50+50+50+50+50} \times 100 \% \\
& \text { Persentase kelayakan }(\%)=\frac{203}{250} \times 100 \% \\
& \text { Persentase kelayakan }(\%)=81,2 \% \\
& \text { Persentase yang didapat sebesar } 81,2 \% \text {, maka dapat dikategorikan sangat layak. Hasil } \\
& \text { digunakan untuk mendeskripsikan adalah data persentase serta pertanyaan pendukung yang } \\
& \text { meliputi saran dan penjelasan nilai diatas. Saran dan masukan oleh penguji menjadi bahan } \\
& \text { pertimbangan dalam pembuatan aplikasi Rute Optimum UD Tahu Bandung Cap “ Jempol “ }
\end{aligned}
$$
Raos.

\section{SIMPULAN DAN SARAN}

\section{Kesimpulan}

Berdasarkan data dan variabel yang dilihat dan dianalisis maka dapat disimpulkan bahwa prosedur dan efisiensi waktu dalam pengriman tahu di perusahaan UD Tahu Bandung Cap “ Jempol “ Raos belum terorganisir dengan baik, dengan diterapkannya metode Algoritma genetika dan pembuatan aplikasi ini sehinnga dapat menghasilkan:

1. Dengan penerapan Algoritma Genetika dan aplikasi Rute dalam pencarian rute optimum untuk pengiriman tahu di UD Tahu Bandung Cap “ Jempol “ Raos, pengiriman tahu lebih efektif dan efisien sehingga lebih optimal dalam proses pendistribusian tahu dan secara otomatis akan meminimalisir biaya distribusi.

2. Dengan penerapan Algoritma Genetika dan aplikasi Rute dalam pencarian rute optimum untuk pengiriman tahu di UD Tahu Bandung Cap “ Jempol “ Raos, pengiriman tahu lebih terorganisir dan data yang dibutuhkan driver ketika proses pendistribusian tahu lebih jelas sehingga lebih meminimalisir keterlambatan pengiriman dan kesalahan pengiriman tahu.

\section{Saran}

Berdasarkan batasan yang ada pada hasil penerapan metode Algoritma Genetika pada aplikasi Rute Pengiriman di UD Tahu Bandung Cap “Jempol” Raos ini penulis sistem memberikan beberapa saran seperti dibawah ini: 
1. Untuk pengguna dan pembaca diharapkan dapat melanjutkan perumusan Algoritma Genetika ini dengan menambahkan variabel yang lebih kompleks dalam penentuan jalur optimum tersebut.Karena variabel yang digunakan dalam penentuan rute optimum saat ini adalah jarak tempuh.

2. kepada pengguna dan pembaca diharapkan bisa menghubungkan aplikasi lain dengan aplikasi yang dirancang ini misalnya dengan aplikasi waze dll karena aplikasi yang terhubung saat ini adalah google maps.

\section{DAFTAR RUJUKAN}

Anies Hannawati, T. E. (2002). Pencarian Rute Optimum Menggunakan Algoritma Genetika.

Basuki, Achmad. Algoritma genetik (World Wide Web: http://www2.eepisits.edu/ basuki/lecture/AlgoritmaGenetika.pdf, Diakses pada 11 September 2017).

Harim Adi Saputro, Wayan Firdaus Mahmudy, Candra Dewi. (2015). IMPLEMENTASI ALGORITMA GENETIKA UNTUK OPTIMASI PENGGUNAAN LAHAN PERTANIAN .

Haupt, Randy L. dan Haupt, Sue Ellen. 2004. Practical Genetic Algorythms Second Edition. s.l. : John Wiley \& Sons, 2004.

Kartika Gunadi (mahasiswa), I. K. (2013). "OPTIMASI PENYUSUNAN BARANG DALAM RUANG TIGA DIMENSI MENGGUNAKAN METODE GENETIC ALGORITHMS"

M Top , Syarifudin . Prototyping model [bagus] (World Wide Web http://www.academia.edu/7478616/Prototyping_Model_bagus_ diakses pada 11 September 2017 ).

Maya Sagita Walalangi, A. D. (2012). Penjadwalan dan Penentuan Rute Kendaraan pada Industri Bahan Kimia Menggunakan Kombinasi Algoritma Genetika dan Algoritma Pencarian Tabu.

Okky Cintia Devi, W. F. (2015). Penerapan Algoritma Genetika untuk Penjadwalan Asisten Praktikum.

Pressman, Ph.D, R. S. (2012). Rekayasa Perangkat Lunak. Yogyakarta: Andi.

Ramdhani, G. (2015). Penerapan Algoritma Genetika untuk Optimalisasi Penyusunan Kemasan Produk di Coldstorage dengan Sistem First-In, First Out .

Sugiyono. 2013. Metode Penelitian Pendidikan Pendekatan Kuantitatif, Kualitatif, dan R\&D. Bandung: Alfabeta.

Sugiyono. 2010. Metode Penelitian Administratif. Bandung: Alfabeta.

Suyanto. (2005). Algoritma Genetika dalam Matlab. Yogyakarta: Andi Publisher.

Suyanto. (2005). Algoritma Genetika dalam MATLAB. Yogyakarta: Andi Offset.

Zukhri, Z. (2014). Algoritma Genetika. Yogyakarta: Andi Publisher.

Zukhri, Zainudin. 2014. Algoritma Genetika Metode Komputasi Evolusioner untuk Menyelesaikan Masalah Optimasi. Yogyakarta : Penerbit Andi, 2014. 